\begin{tabular}{|l|l|l||}
\hline \multicolumn{2}{|c|}{ PublisherInfo } \\
\hline \hline PublisherName & $:$ & BioMed Central \\
\hline \hline PublisherLocation & $:$ & London \\
\hline \hline PublisherImprintName & $:$ & BioMed Central \\
\hline \hline
\end{tabular}

\title{
Antioxidant effect of estrogen may protect heart cells from inflammation
}

\begin{tabular}{||l|l|l||}
\hline \multicolumn{2}{|c||}{ ArticleInfo } \\
\hline \hline ArticleID & $:$ & 24 \\
\hline \hline ArticleDOI & $:$ & $10.1186 /$ cvm-2001-72158 \\
\hline \hline ArticleCitationID & $:$ & 72158 \\
\hline \hline ArticleSequenceNumber & $:$ & 3 \\
\hline \hline ArticleCategory & $:$ & Paper Report \\
\hline ArticleFirstPage & $:$ & 1 \\
\hline \hline ArticleLastPage & $:$ & 3 \\
\hline \hline & & RegistrationDate : 2001-10-19 \\
ArticleHistory & $:$ & Received $\quad: 2001-1-18$ \\
& & OnlineDate $\quad: 2001-10-19$ \\
\hline \hline ArticleCopyright & $:$ & Biomed Central Ltd2001 \\
\hline \hline
\end{tabular}




\begin{tabular}{|l|l|l|}
\hline ArticleGrants & $:$ & \\
\hline \hline ArticleContext & $:$ & 1306322 \\
\hline
\end{tabular}

Joanna Lyford, ${ }^{\text {Aff1 }}$

Corresponding Affiliation: Aff1

Aff1 MedWire, UK

Keywords

Adhesion molecules, atherosclerosis, cytomegalovirus, estrogens, free radicals, inflammation

\section{Context}

Estrogen has proved effective in inhibiting cytomegalovirus (CMV) infection and may protect heart cells from the damaging effects of inflammation. The inflammatory response in the body leads to the production of oxygen free radicals, which can contribute to plaque build-up in the coronary arteries, potentially blocking blood vessels.

Scientists from the National Institute of Health in Bethesda, Maryland, USA, studied smooth muscle cells taken from a premenopausal woman's coronary artery, which were pretreated with different molecular forms of estrogen.

\section{Significant findings}

17?-estradiol and its stereoisomer 17a-estradiol dose-dependently inhibited ROS generation in the CMV-infected human coronary artery smooth muscle cells (SMCs). However, the estrogen receptor inhibitor ICI 182780 did not block these effects. In addition, 3-Methoxyestrone, which lacks the phenolic hydroxyl group, did not interfere with ROS generation. 17?-estradiol and 17a-estradiol, but not 3-methoxysterone, also prevented binding of nuclear factor-kB to DNA. CAT activity was inhibited, and in CMV-infected SMCs, IE72 and ICAM-1 protein expression and cytopathic effects were prevented by treatment with 17?-estradiol and 17a but not 3-methoxysterone. 


\section{Comments}

The authors postulated that estrogen molecules with an A-ring hydroxyl group are capable of blocking free radicals and inhibiting the inflammation process, as well as preventing replication of the virus. However, Dr Richard O Cannon III, who led the study warns: 'Because the study was conducted on cells, and not in humans, we do not yet know if the same results will be found in human studies.' The authors hope that the antioxidant actions of estrogen may have therapeutic effects and could inhibit viral and cellular inflammatory genes, which may contribute to atherogenesis in susceptible women.

\section{Methods}

Using confocal microscopy and an intracellular fluorescent dye activated by reactive oxygen species (ROSs), the researchers compared the protective abilities of estrogen against exposure to CMV.

\section{Additional information}

\section{References}

1. Speir E, Yu Z-X, Takeda K, Ferrans VJ, Cannon RO III: Antioxidant effect of estrogen on cytomegalovirus-induced gene expression in coronary artery smooth muscle cells. Circulation. 2000, 102: 2990-2996.

This PDF file was created after publication. 